\title{
The analysis and creation of landscape aesthetic value network models as important elements of sustainable urban development
}

\author{
Anna Maria Kowalczyk \\ University of Warmia nad Mazury, Oczapowskiego 2, 10-900 Olsztyn, Poland
}

\begin{abstract}
Landscape potential management is a very important aspect of sustainability development of the urbanized area. The knowledge of the city landscape value and correct management of the potential that landscape has, helps to optimize activities in land management and to keep spatial order. Studies which are described in this article include creation and comparative analysis of two landscape aesthetic value network models: a network model of landscape value generated according to the way of minimal increase of landscape value and the one generated according to the way of the minimal fall of landscape value. Those activities should lead to creating a method for constructing a network model of landscape value of urbanized area. This method can be applied as a basic for optimizing the organization of space planning and landscape management.
\end{abstract}

Keywords: network model; ladscape, urban, sustainability.

\section{Introduction}

Sustainable development is defined as the: Process aiming at satisfying development aspirations of the current generation in the way allowing accomplishment of the same goals by the consecutive generations" [13]. Such a process encompasses social, economic and environmental changes that would assure balance between benefits and costs of development in the perspective of the future generations also. That development should reflect the policy and strategy of continual economic and social development without harm to the environment and natural resources as retaining those elements is the condition for continuation of human life and activities and further human development. Currently, the development became the manifestation of success. It is one of the fundamental goals of all political activities. However, side effects of uncontrolled development or development that was optimal in only one selected aspect, e.g. the economic aspect, are observed increasingly clearly. Hence, stimulating the process of development itself as well as preventing unfavourable phenomena that it can induce should be the aim of the spatial policy of towns. In the light of those issues, the search for new spatial analysis methods and tools that would assure sustainable development of urbanised areas is an important issue [6]. Those areas, as well as the neighbouring areas frequently develop in a very intensive way destroying the landscape, which is a very important component shaping the space and changes of which should be controlled while all the activities should be optimised to preserve the landscape for the future generations. Unfortunately, management of the landscape potential of urbanised areas is frequently conducted in entirely intuitive way without applying any scientific methods leading to optimisation of decisions. The test area that was subject to analysis in this paper is rather specific. Olsztyn is a city situated in north-eastern Poland possessing unique landscape potential important from the perspective of spatial policy. Within the city limits there are 11 lakes and over 1850 hectares of forests (the woodiness of the city exceeds $21 \%$ ). All forms of green areas in the city represent over $50 \%$ of the city area. The valley of the Łyna River runs across the city. Given that information it is not difficult to conclude that tourist and recreation functions belong to its leading functions, next to the economic, educational and cultural functions in the region and that the landscapes and their aesthetic value represent the unique value. Maintaining and appropriate management of the landscape potential represent in this case the existential base of the city as an important urban centre in the region of Warmia and Mazury as well as in the national and global scale. Currently, landscape is an economic good, differing significantly from conventional economic goods and services because its use usually does not involve market transactions. Landscape in itself is not the object of trade. Market determined

Corresponding author: Anna Maria Kowalczyk. E-mail address: anna.kowalczyk@uwm.edu.pl

http://dx.doi.org/10.3846/enviro.2014.123

(C) 2014 The Author. Published by VGTU Press. This is an open-access article distributed under the terms of the Creative Commons Attribution License, which permits unrestricted use, distribution, and reproduction in any medium, provided the original author and source are credited. 
measures of its value - process do not exist in its case. On the other hand, it can be said that attractive landscape is an economic good because people are ready to pay for it. The payment for landscape as a good can be "hidden" in, e.g. the price of real property or it may have the direct form as, e.g. the entrance fee for access to places possessing significant landscape value. Currently, increasing outlays are made for environment protection and anthropogenous support of landscape reconstruction processes. Hence the opinion that all natural resources possess some value [2].

Landscape can be described as the entire complex of spatial phenomena formed on the Earth surface by both the nature and under the human cultural activity. Those phenomena represent the expression of a given place and moment and for every one of us they represent a space-time characteristic that we notice and subject to evaluation [12, 14]. Analysing urbanised areas the role of the landscape can be described in the schematic way as a determinant of economic development (Fig. 1).

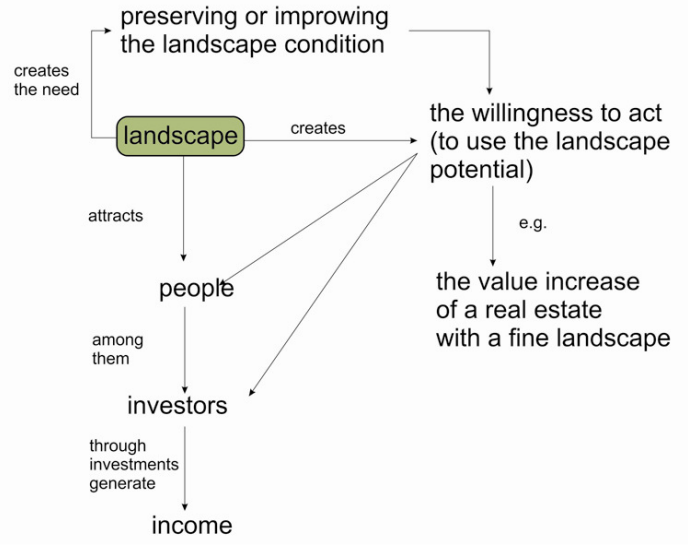

Fig. 1. The role of landscape as a determinant of economic development. Source: [10]

This paper presents a proposal of using the methodology for development of the landscape aesthetic value network models as a good tool for conducting analyses representing a component of town development policy including undertaking specific actions in the area of landscape potential management. It should be highlighted that the results of analysis described below are specific for the given study area, however, the methodology proposed is of universal character applicable to any space chosen.

\section{Creation of landscapes aesthetic value network models}

Conducting numerous geospatial analyses was necessary for development of landscape aesthetic value network models. Those analyses are very important, in particular the methods of open source geoinformation analyses [3]. The space that we subject to evaluation is composed of numerous components, characteristics of the space that we can call geodata. Appropriate choice and quality of geodata allows obtaining good, accurate spatial information (geoinformation, which in turn allows us taking optimal decisions. Hence, appropriate evaluation elements and methodology had to be chosen to evaluate the aesthetic value of the landscape and to be able to use the data and information in the process of optimal landscape potential management. From among very many proposed methods of landscape evaluation and valorisation [2, 5] the impressions curve method by Wejchert [15] modified by Bajerowski [2, 5] was applied.

That method serves evaluation of visual attractiveness of urban time-space sequences. It has been adapted for evaluation of the rural areas' open landscape e.g. in Poland by C, H, K, M-B [8]. Moreover, the "S" software and urban landscape evaluation cards described by Kowalczyk [10] were used. Using the above indicated methods, more than 1500 data items on the aesthetic landscape value in the analysed area were gathered and organised. The data items were presented by the individual basic fields of landscape aesthetic value evaluation. Figure 2 presents the network of basic evaluation fields set on the analysed urbanised area with the locations of evaluation points marked.

Development of the landscape aesthetic value network models was the next step. Cohen [7] formulates the thesis that "All the world's a Net". Numerous issues concerning the theory of networks, their design and characteristics are also described by B [4]. The theory of spatial connections and development of networks found also application in studies on the dynamics of the development of regions and in spatial management [1]. Out of six proposed rules of spatial connections that serve network development described by Kowalczyk [9] after Bajerowski and Biłozor [1] two: minimum increase in value and minimum decrease in value were chosen for further analyses. Those two methods use the estimated aesthetic values in the most optimal way. The figure presented below (Fig. 3) presents the principle of creating the landscape aesthetic value network model according to the minimum decrease in value rule.

The landscape aesthetic value network model using the minimum increase in value rule is presented in the same way as the one presented above with the difference that the values (nodes) are connected where the minimum increase in value occurred. The important assumption is that the node may be connected to the neighbouring nodes (fields) only. 


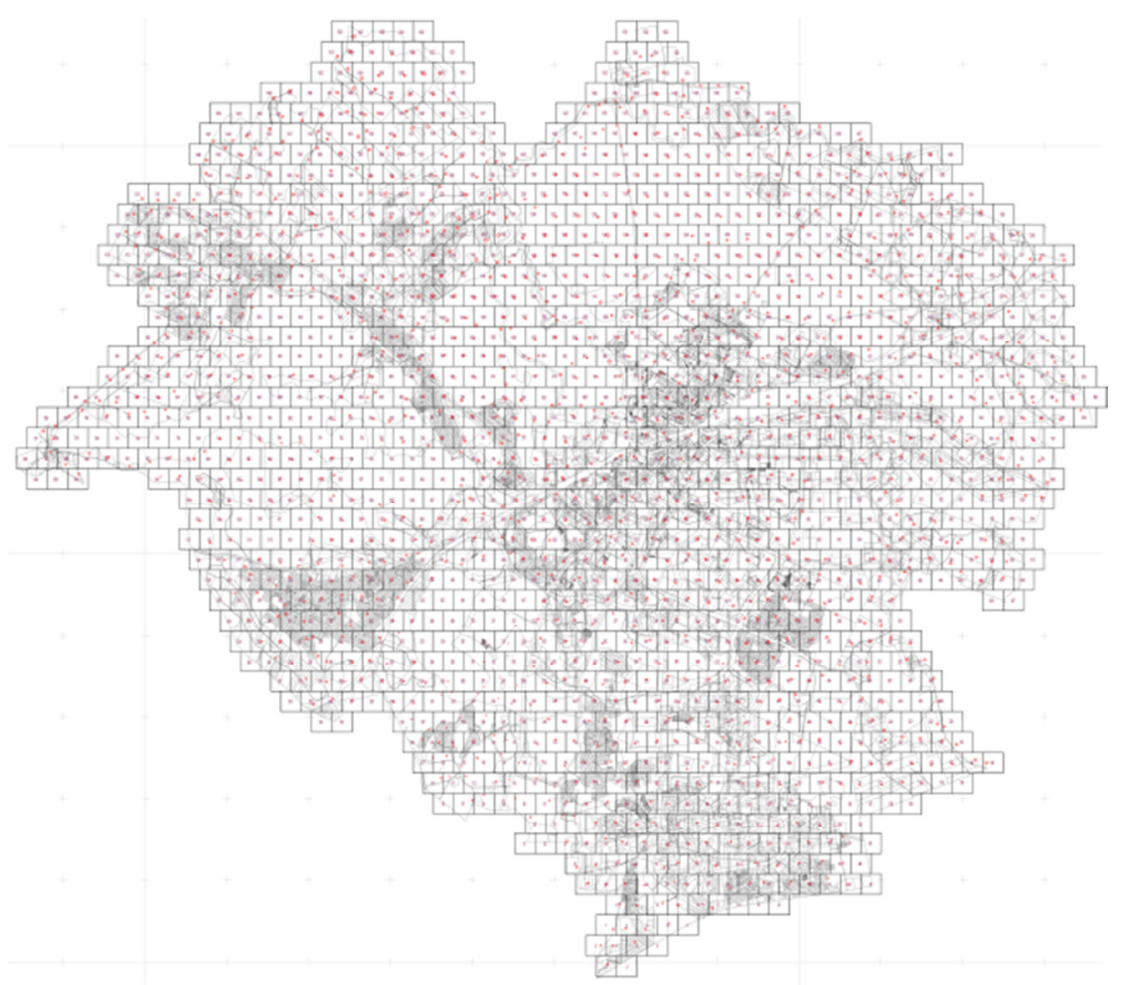

Fig. 2. The researched area-Olsztyn city with basic unit grid of landscape aesthetic value and assessment viewpoints (red spots) marked on it. Source: Own study in the "EWmapa" computer program

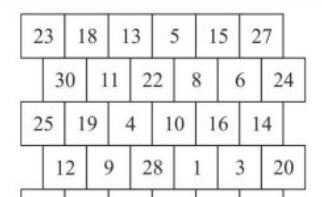

a)

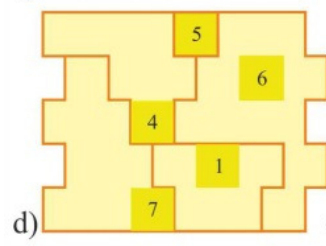

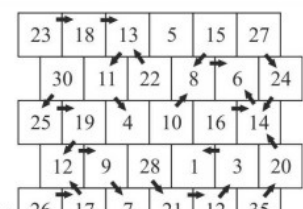

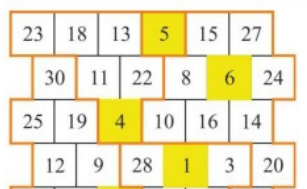

b)

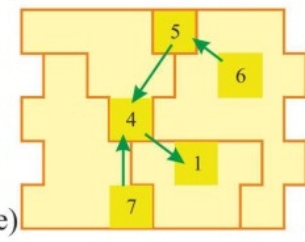

c)

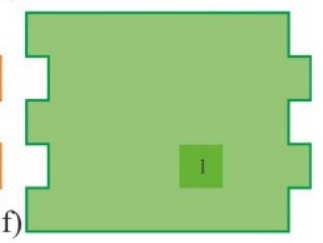

Fig. 3. Schematic deductive example of drawing up a network model according to the minimal decrease in value rule: a) basic fields of assessment with illustrative values; b) the initial step of combining values in the way of minimal increase; c) the first level of aggregation: yellow fields - nodes of newlyformed "regions"; orange lines - the borders of those "regions" d) the first level of aggregation; e) combining values in the way of minimal increase on the second level of aggregation; $f$ ) the last - second level of aggregation. Numbers from 1 to 35 - value in nodes

As can be seen in the above figure, the network is created in the processes of aggregation the number of which depends on the magnitude and distribution of the data until the point of connecting all the data into the network. In the network described in that way we can identify the nodes that represent values allocated to evaluation points in every basic field of landscape aesthetic value evaluation and the connections that represent dependences of values of the minimum increase or minimum decrease of the landscape aesthetic value.

In these studies two network models were developed:

- the network model of landscape value generated according to the minimum increase in value;

- the network model of landscape value generated according to the minimum decrease in value.

\subsection{The network model of landscape value generated according to the way of minimum increase in value}

In the first analysed landscape aesthetic value network developed based on the minimum increase of that value the following can be identified:

- nodes (positive nodes) - nodes formed by the minimum increase in value, at the different levels of aggregation.

- connections - appearing according to the rule of minimum increase in value, as in Figure 3.

As concerns this network, the name "positive nodes" is proposed because connecting those nodes according to the minimum increase in value rule the landscape aesthetics in those nodes is the highest. In the above-presented network 
model, two positive nodes that play the most important role in the entire model can be identified. Those nodes are the points to which all the connections go and hence, further in this paper they will be referred to as the positive centres. They represent two most attractive places from which the most attractive landscape within the analysed area can be seen (Fig. 5a and Fig. 5b). Those locations with the landscape aesthetics value scores of 3101 points are marked by black circles in Figure 4.

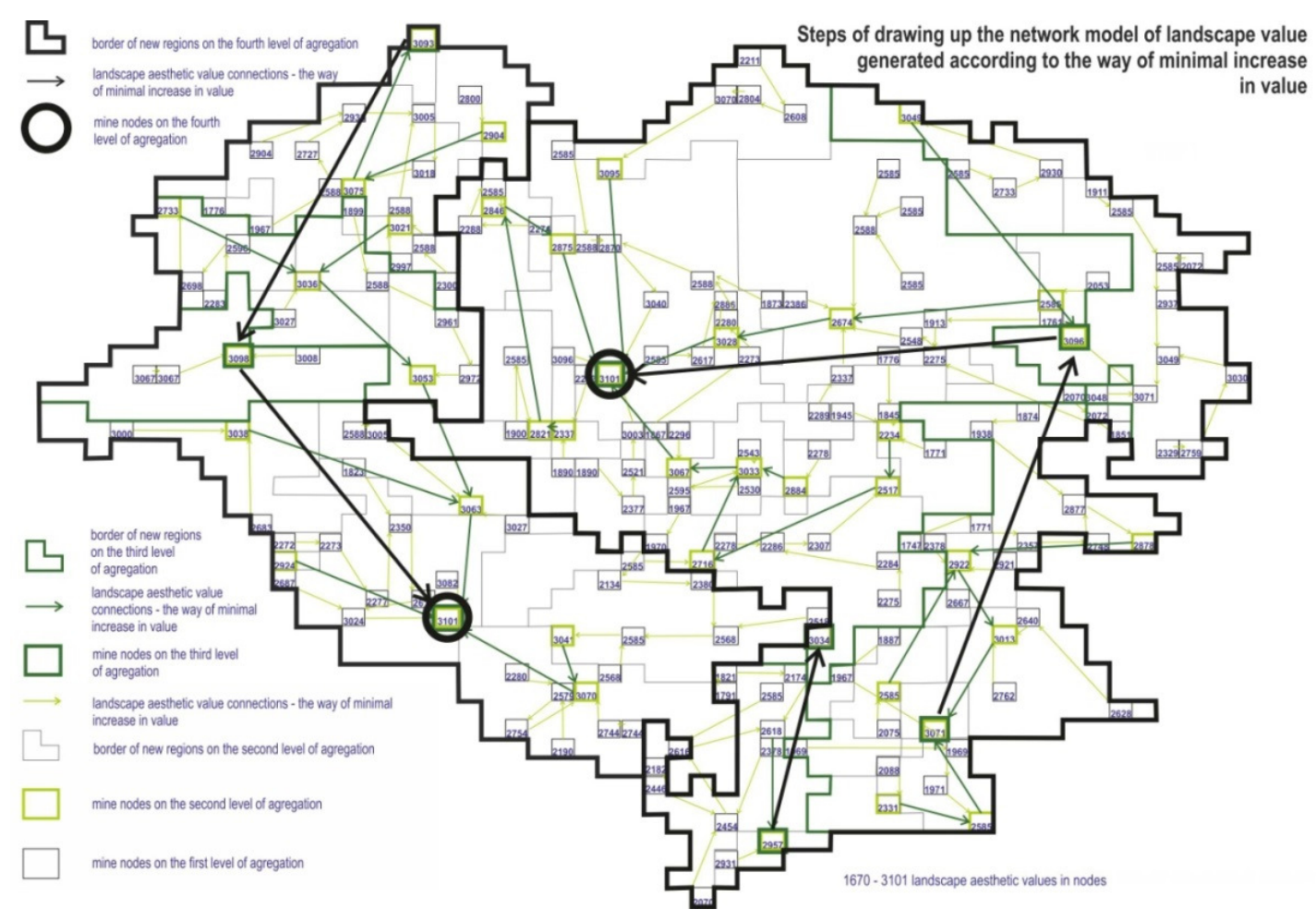

Fig. 4. Steps of drawing up the network model of landscape value generated according to the way of minimum increase in value
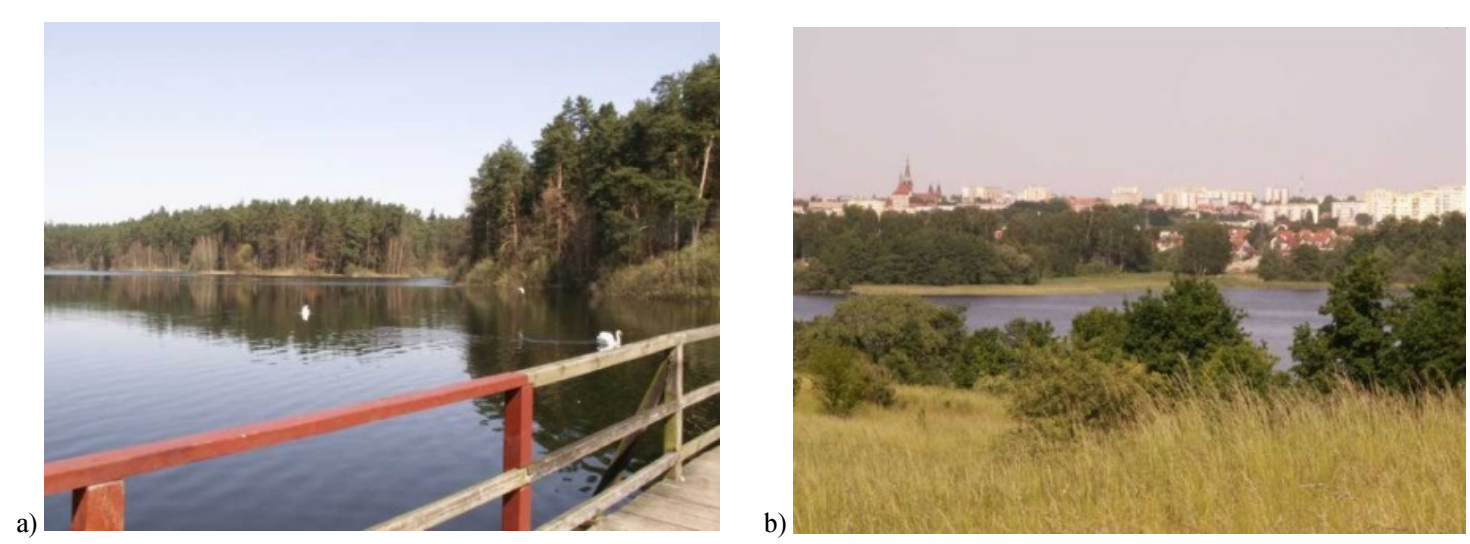

Fig. 5. The most important nodes in the network model of landscape value generated according to the way of minimum increase in value, present landscapes of the highest aesthetic value. They are accordingly two the most attractive views in the research area

The positive nodes in the discussed network are positioned in different points of the analysed area, at the similar distances between them, with the exception of the northern part of the city (municipal forest - similar values). That positioning of nodes indicates that the phenomenon of "nice landscape" centralisation in one, specific area of the city has not taken place. This is positive and confirms attractiveness of the entire analysed area. Positive nodes reveal locations where the landscapes are the most attractive at the individual aggregation (detail) levels. Those are mainly areas in the vicinity of lakes and rivers, green areas and developed spaces.

Based on the landscape aesthetic value network model developed according to the minimum increase in value rule it is possible to conduct analysis presenting how in spatial terms the aesthetic landscape value increases and based on that the landscape can be managed in the optimal way. Development of walking paths, tourist routes and didactic cycling paths or recreation places, etc. in the way allowing increase of aesthetic experience of the users can be an example. 


\subsection{The network model of landscape value generated according to the way of minimum decrease in value}

The second analysed landscape aesthetic value network developed according to the minimum decrease in value rule (Fig. 6) possesses in its structure the:

- nodes (negative nodes) - nodes formed by the minimum decrease in value, at the different levels of aggregation,

- connections - appearing according to the rule of minimum decrease in value, in the same way as in Figure 3.

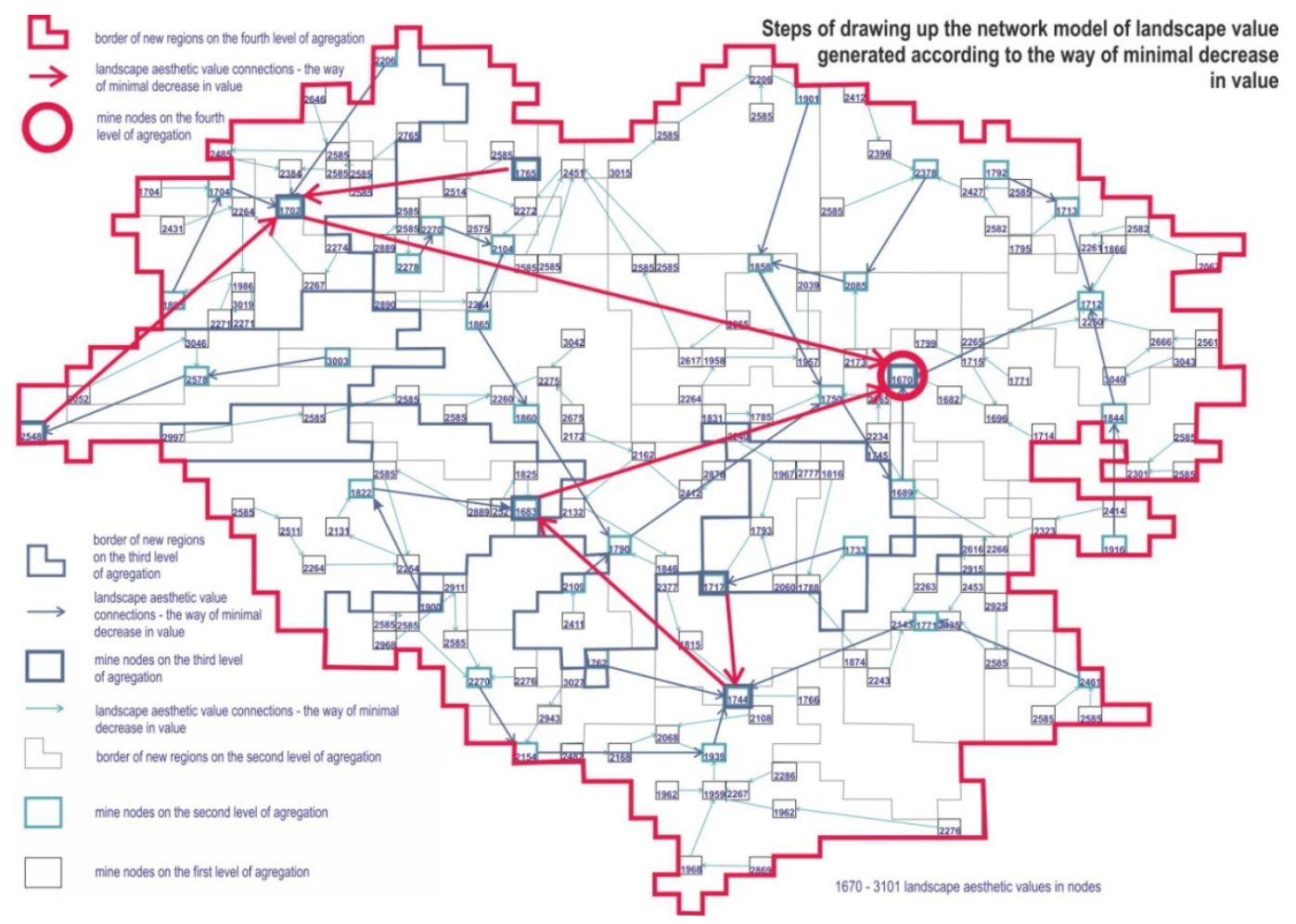

Fig. 6. Steps of drawing up the network model of landscape value generated according to the way of minimum decrease in value

In case of that network the use of the term "negative nodes" is proposed as by connecting nodes according to the minimum decrease in value rule the nodes are identified where the landscape aesthetic values are the lowest.

The landscape aesthetic value network model generated according to the minimum decrease in value rule has one negative node to which all the connections go. Similar to the network analysed above, that node will be referred to as the centre, but in this case the negative one. This is the point from which the least attractive landscape within the entire analysed area can be seen. The other negative nodes that were generated at lower aggregation levels are spread relatively evenly with the exception of the northern part of the area of analysis and some border areas. This is related to the location of the municipal forest in the northern part of that area as well as the open greenery areas. Negative nodes reflect the most neglected, frequently devastated places. In the analysed case the landscape of the railway station area is the negative centre (Fig. 7).

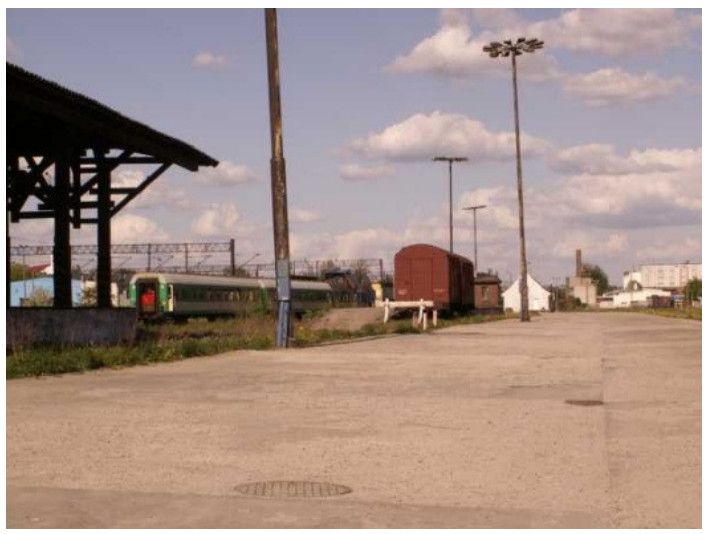

Fig. 7. The most important node in the network model of landscape value generated according to the way of minimum decrease in value, present landscape of the lowest aesthetic value. This is accordingly the lowest attractive views in the research area 
The model of this network represents an excellent complement to the model presented above. While the landscape aesthetic value network model developed according to the minimum increase in value rule presents the most attractive places that should be treated as development potential of the city, this model shows places representing a threat - the negative centre and nodes.

This translates into activities related to optimisation of tourist, recreational and cultural space of the town organisation. Positive centres and nodes should be protected and developed as well as used for design activities. The landscape aesthetic value network model generated according to the minimum loss in value rule should also be considered in such activities but in a different aspect. The negative centre and nodes represent the least attractive landscapes and in case of design activities they should be avoided, eliminated from the network structure by increasing their aesthetic value.

\section{Conclusions}

The studies aimed at presenting how important a role in sustainable development of urbanised areas optimal landscape management plays and proposing a methodology for generating landscape aesthetic value network models as a good tool supporting those activities.

The entire scope of conducted studies and their results allowed formulating the following conclusions:

- positive centres and nodes should be the points offering satisfaction with the view and additionally they should possess other strengths (e.g. those locations should be complemented with infrastructure such as sports facilities, gastronomy, museums, etc.). A person taking a walk wants to amplify the aesthetic experiences and reach the specific destination of the trip grading the aesthetic experiences. That destination (the positive centre) should possess the largest number of strong points. Optimisation of activities should also contribute significantly to preserving and protecting the existing landscapes so that the consecutive generations could enjoy them and hence those landscapes should represent an important element of the sustainable development. The model generated shows those places clearly as positive centres and nodes.

- the positive centre is a specific point on the surface of the Earth. It should be subject to particular protection. However, the landscape seen from that point should be subject to even more extensive protection. In this study the most attractive landscapes are open landscapes. Such a landscape is destroyed as a result of introducing close elements obstructing the landscape seen entirely or partly or introducing "far away" elements impairing it. Destruction of the centre may occur by, e.g. physical destruction of the observation point (bomb, privatisation and fencing of the area, construction of buildings that makes viewing impossible, etc.) or destruction of the accompanying atmosphere by, e.g. a source of nasty odour making concentration and positive perceptions impossible, pollution by waste, etc. The model also offers the possibility of conducting the simulation of excluding the node from the network structure and conducting the analysis of which node could take over its function and what actions should be taken, e.g. what should be changed in the landscape to increase its aesthetic value.

- the existing network model of relations in landscape aesthetics allows identification of locations with strong influence on the development of tourist and recreation functions. Positive centres and nodes requiring retention and support by landscape modelling as well as tourist service facilities were identified. Positive nodes can be subjected to transformation into positive centres. This should be represented by the process within which the landscape would be subject to aesthetic transformations increasing its attractiveness coupled with providing tourist services and safety of people and the landscape itself. Such actions lead to increasing the functionality of the space as the whole structure in case of, e.g. dysfunction of one or more positive centres. Within the networks the negative centres were also made clearly visible. They should be "eliminated" by improving the aesthetics of those locations. Those transpositions would have to be based on managing the information on the landscape. Accomplishment of that objective would require development of landscape information database that would expand significantly the GIS of the city of Olsztyn.

- the models generated possess universal value as concerns the scale of the analysed area. Optimisation of the process of taking decisions on land development and design work may apply to both micro-scale (individual estates or areas) and macro-scale (the entire analysed area).

- the data gathered was also used to create the map of landscape aesthetic value [11], which, using the actual isarithms, shows the distribution of those values across the given areas of analysis.

Summarising the above-described studies it should be highlighted that the models generated should represent a very important element in planning sustainable development of urbanised areas providing the clear image of the landscape aesthetic value potential in a given area.

\section{References}

[1] Bajerowski, T.; Biłozor, A. 2005. Theory of Barabasi scale-free networks as a new tool in researching the structure and dynamics of regions, in Regional scientists' tribute to professor Ryszard Domański., Studia Regionalia 15 : 209-230. ISSN 0860-3375.

[2] Bajerowski, T.; Biłozor A.; Cieślak I.; Sanetra A.; Szczepańska A. 2007. Ocena i Wycena Krajobrazu. Poland - Olsztyn - Educaterra.

[3] Bajerowski, T.; Kowalczyk A. 2013. Metody geoinformacujnych analiz jawnoźródłowych w zwalczaniu terroryzmu. Poland - Olsztyn -Wydawnictwo Uniwersytetu Warmińsko-Mazurskiego w Olsztynie.

[4] Barabási, A.-L. 2003. Linked, Penguin Group 
[5] Cieślak, I.; Biłozor, A.; Konieczna, J.; Mróz, M.; Szumiło, M.; Szuniewicz, K.; Trystuła, A. 2012. Wspótczesna waloryzacja przestrzeni zurbanizowanej. Poland - Olsztyn - Wydawnictwo Uniwersytetu Warmińsko-Mazurskiego w Olsztynie.

[6] Cieślak, I.; Gerus - Gościewska, M.; Szuniewicz, K. 2013. The application of genetic algotirhms as a tool for supporting the processes of analysis and predicting urban development. Regional Development, Spatial Planningand Strategic Governance. I Institute of Architecture and Urban \& Spatial Planning of Serbia. $350 \mathrm{p}$.

[7] Cohen, D. 2002. All the world's a Net, New Scientist 174(2338): 24-29.

[8] Cymerman, R.; Hopper, A. 1988. Zastosowanie metody Söhngena do oceny wartości przyrodniczych krajobrazu obszarów wiejskich. Zeszyty Naukowe Akademii Rolniczo-Technicznej w Olsztynie. 18.

[9] Kowalczyk, A. 2009. Zastosowanie teorii sieci bezskalowych Barabasi'ego w procesie optymalizacji organizacji przestrzeni turystycznej na przyktadzie miasta Olsztyna. PhD dissertation, University of Warmia and Mazury in Olsztyn.

[10] Kowalczyk, A. 2012. Valuation and Valorisation of Urban Landscape in Olsztyn, Urban Public Space - Economics And Management Perspectives Polish Academy of Science, 77-94.

[11] Kowalczyk, A. 2012. The iconic model of landscape aesthetic value, European Spatial Research and Policy 2: $121-128$.

[12] Luczyńska-Bruzda, M. 1978. Ochrona krajobrazu, Ochrona i ksztaltowanie środowiska przyrodniczego. II. PWN Warszawa.

[13] Report of the World Commission on Environment and Development, 1987, United Nations, http://www.un.org/documents/ga/res/42/ares42-187.htm

[14] Skalski, J. A. 2007. Analiza percepcyjna krajobrazu jako działalność twórcza inicjujacca proces projektowania. Wydawnictwo Szkoły Głównej Gospodarstwa Wiejskiego, Warszawa

[15] Wejchert, K. 1974. Elementy kompozycji urbanistycznej. Wydawnictwo Arkady. Warszawa. 